\title{
IDENTIFICATION OF MATHEMATICALLY GIFTED PUPILS OF LOWER SECONDARY SCHOOLS
}

\section{Eva Hotová}

\begin{abstract}
The contribution deals with results of the research focused on characteristics of mathematically gifted pupils. The aim of the research was to involve and describe main signs and abilities of mathematically gifted pupils.
\end{abstract}

\section{Key words}

Gifted pupils, mathematics.

\section{Identifikace matematicky nadaných žáků na 2. stupni základních škol}

\begin{abstract}
Abstrakt
Příspěvek pojednává o výsledcích výzkumného šetření, jehož cílem bylo postihnout a popsat hlavní společné znaky a schopnosti matematicky nadaných žáků.
\end{abstract}

\section{Klíčová slova}

Nadaní žáci, matematika.

\section{Introduction}

The identification of a gifted child is not easy thanks to uniqueness of each individual. We can find in each of them different combination and intension of personality characteristics, abilities, behaviours. There is a question whether there are some signs and abilities that would be common to majority of mathematically gifted pupils. This question became a base for the formulation of our research issue.

Are there any signs and abilities typical for a mathematically gifted pupil in comparison with a "normal" pupil? 
The research was led at five different elementary schools in Olomouc during the school year 2008. The sample consists of $8^{\text {th }}$-graders from 11 classes. All together it was 204 pupils. 20 respondents were removed from the research because they did not take part in both phases of the research.

The pupils were divided (on the basis of set criteria) into two disjunctive groups: mathematically gifted pupils and "normal" pupils.

Criteria for selection of mathematically gifted pupils were formulated as follows:

1. the result on the standardized test Kalkulie IV.

2. excellent results in mathematics (in $7^{\text {th }}$ grade)

3. taking part in mathematical activities

4. described by teacher as creative, original in solving problems, with excellent knowledge, with interest in mathematics etc.

A pupil to be called mathematically gifted has to fulfil at least three of the four given criteria.

To gain the needed data we used the standardized test of mathematical abilities Kalkulie IV., non-standardized didactic test of mathematics created by the author and an interview with math teachers of the classes which took part in the research. We used methods of quantitative research to verify individual hypotheses. All hypotheses were tested at the significance level $\alpha=0.05$.

The test Kalkulie IV. was administered in group form. Time of testing is set by the author J. Novák (2002) to 25 minutes. It is a standardized test identifying the mathematical quotient (MQ) of children from the age of 10 to 16 years. It is different from usual mathematical school tasks. It is not given only by numerical operations. While solving the tasks respondent is stimulated by spatial structure of stimuli. The test concludes 36 tasks with increasing demandingness.

Didactic test concluded 13 tasks and it took 40 minutes. The tasks were mainly open with brief ( 3 tasks) and wide ( 9 tasks) possibility of answer. One of the tasks is a select task, with the possibility of multiple-choice answers.

While testing pupils were seated alone in their desks. Testing was conducted with the agreement of the school headmaster in two days in the morning.

Teacher's interview in each class was conducted after individual agreement with the teacher and it was needed to gain information necessary to decide the fulfilling of criteria set for pupils division. The aim was to gain information:

- about the results of pupils in mathematics in summer semester of the $7^{\text {th }}$ grade, 
- about the participation of pupils and their success in mathematical competitions, olympics,

- about the level of originality, creativity of pupils in solving tasks in mathematics lessons.

The answers were recorded while interviewing.

\section{Results of the standardized test Kalkulie IV. (Test no. 1).}

We set the MQ of all tested students according to the results in Kalkulie IV. test (see Graph no. 1). If we compare the distribution of MQ of the research sample with the data in Novak (2002), we find out that most of the pupils is in the range of average results. On average pupils gained 104 points in Kalkulie IV., the most common results were 106 and 109 points.

Graph no. 1 Percent occurrence of MQ of the research sample

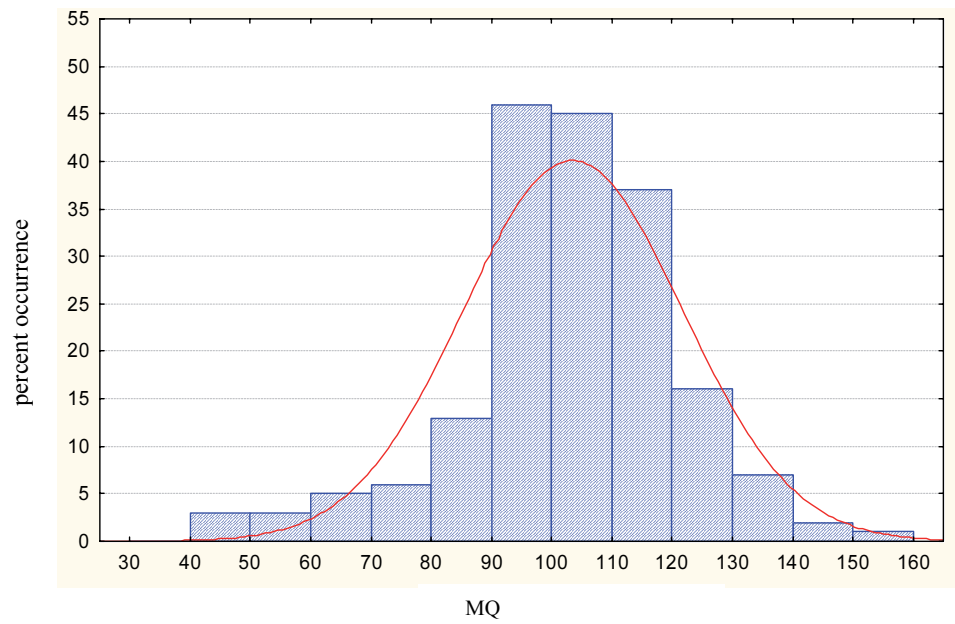

Table no. 1 Average, minimal and maximal value of MQ of the research sample

\begin{tabular}{|c|c|c|c|c|c|}
\hline variable & average & $\begin{array}{c}\text { standard } \\
\text { deviation }\end{array}$ & $\begin{array}{c}\text { minimal } \\
\text { value }\end{array}$ & $\begin{array}{c}\text { maximal } \\
\text { value }\end{array}$ & $\mathrm{N}$ \\
\hline test no. 1 & 103.5272 & 18.31298 & 46 & 153 & 184 \\
\hline
\end{tabular}


There were several pupils who finished the test before the end of the time limit.

Following graphs and tables show the results of pupils in Kalkulie IV. We divided them according to set criteria in two groups: mathematically gifted pupils and "normal" pupils.

Graph no. 2 Percent occurrence of MQ of mathematically gifted pupils



Table no. 2 Average, minimal and maximal value of MQ of mathematically gifted pupils

\begin{tabular}{|c|c|c|c|c|c|}
\hline variable & average & $\begin{array}{c}\text { standard } \\
\text { deviation }\end{array}$ & $\begin{array}{c}\text { minimal } \\
\text { value }\end{array}$ & $\begin{array}{c}\text { maximal } \\
\text { value }\end{array}$ & $\mathrm{N}$ \\
\hline test no. 1 & 126.7500 & 11.74086 & 106 & 153 & 24 \\
\hline
\end{tabular}


Table no. 3 Average, minimal and maximal value of MQ of "normal" pupils

\begin{tabular}{|c|c|c|c|c|c|}
\hline variable & average & $\begin{array}{c}\text { standard } \\
\text { deviation }\end{array}$ & $\begin{array}{c}\text { minimal } \\
\text { value }\end{array}$ & $\begin{array}{c}\text { maximal } \\
\text { value }\end{array}$ & $\mathrm{N}$ \\
\hline test no. 1 & 100.0437 & 16.50552 & 46 & 135 & 160 \\
\hline
\end{tabular}

Graph no. 3 Percent occurrence of MQ of "normal" pupils

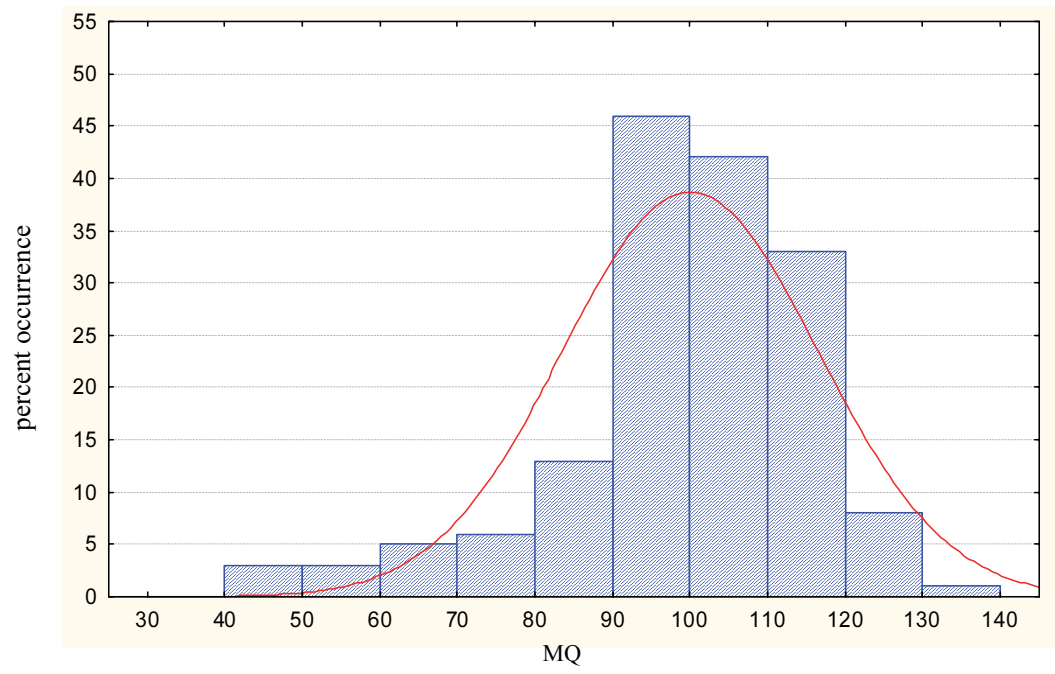

It is obvious from the histograms and tables that the results of both groups in Kalkulie IV. are very different. The difference is 27 points. The average value of MQ of mathematically gifted pupils is higher than the limit we set for criterium 1 .

\section{Results of the didactic test (Test no. 2)}

The didactic test consists of 13 tasks. Pupils get 1 point for every correctly solved task. Therefore, a pupil could get a maximum of 13 points. Results from this test can be seen in Graph no. 4. 
Graph no. 4 Percent occurrence of gained points in didactic test of the research sample

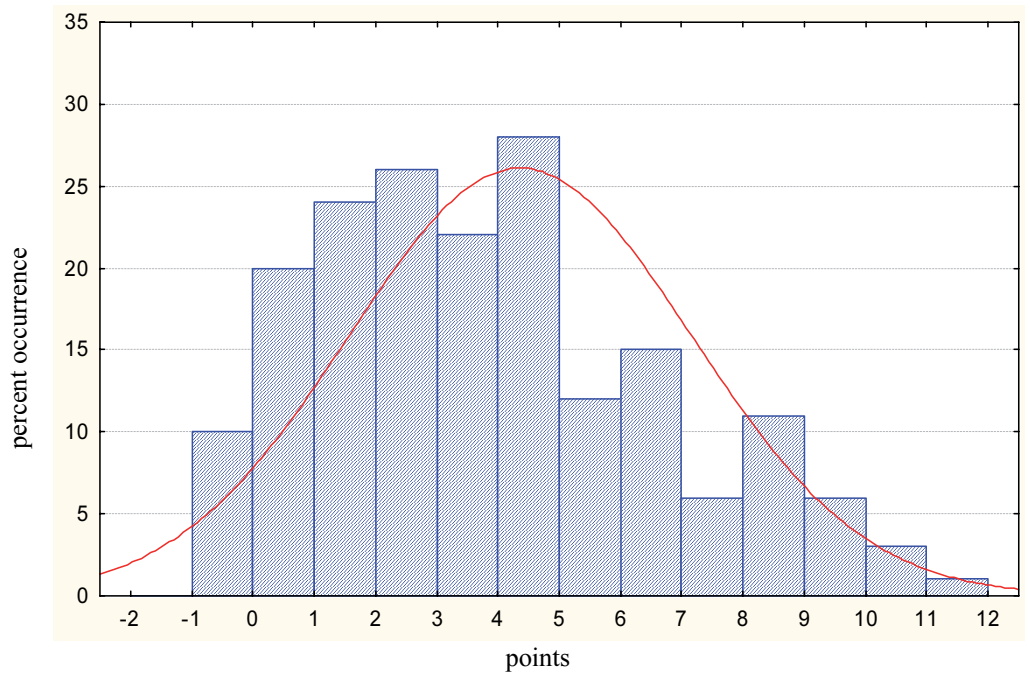

Average result in didactic test (rounded off result) were 4 points, the most common result was 5 points

Table no. 4 Average, minimal and maximal value gained in didactic test of the research sample

\begin{tabular}{|l|c|c|c|c|c|}
\hline \multicolumn{1}{|c|}{ variable } & average & $\begin{array}{c}\text { standard } \\
\text { deviation }\end{array}$ & $\begin{array}{c}\text { minimal } \\
\text { value }\end{array}$ & $\begin{array}{c}\text { maximal } \\
\text { value }\end{array}$ & $\mathrm{N}$ \\
\hline test no. 2 & 4.364130 & 2.811572 & 0 & 12 & 184 \\
\hline
\end{tabular}

The following graphs and tables show the results of pupils in didactic test after division in two groups: mathematically gifted pupils and "normal" pupils. 
Graph no. 5 Percent occurrence of points gained in didactic test of mathematically gifted pupils.

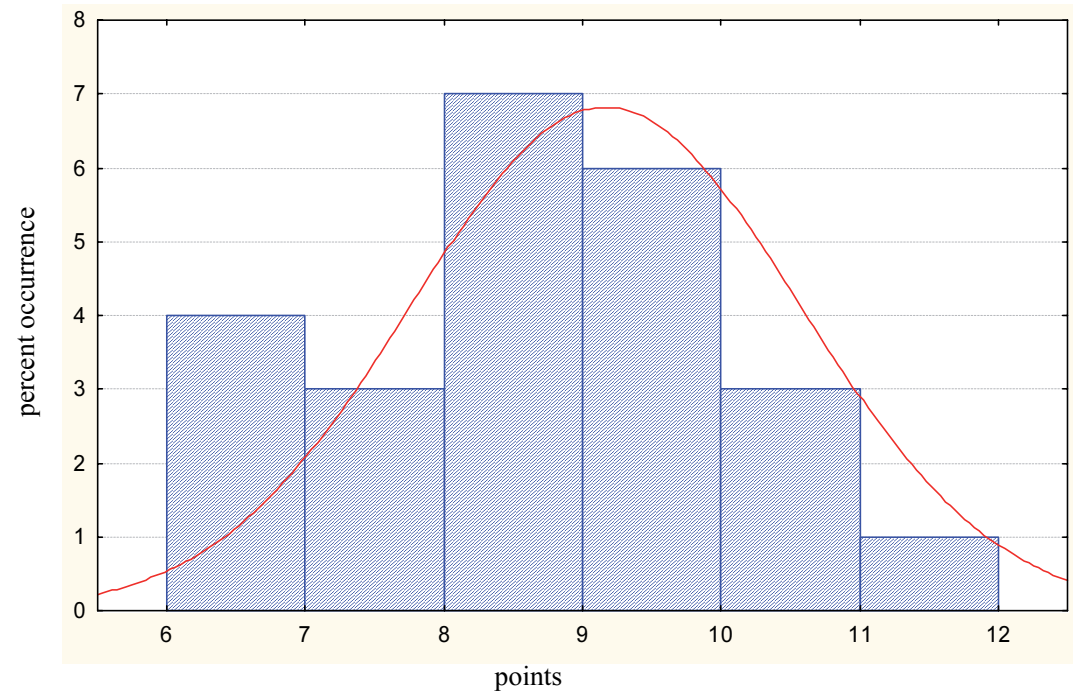

Table no. 5 Average, minimal and maximal value of points gained in didactic test of mathematically gifted pupils

\begin{tabular}{|l|c|c|c|c|c|}
\hline \multicolumn{1}{|c|}{ variable } & average & $\begin{array}{c}\text { standard } \\
\text { deviation }\end{array}$ & $\begin{array}{c}\text { minimal } \\
\text { value }\end{array}$ & $\begin{array}{c}\text { maximal } \\
\text { value }\end{array}$ & $\mathrm{N}$ \\
\hline test no. 2 & 9.166667 & 1.403928 & 7 & 12 & 24 \\
\hline
\end{tabular}


Graph no. 6 Percent occurrence of points gained in didactic test of "normal" pupils

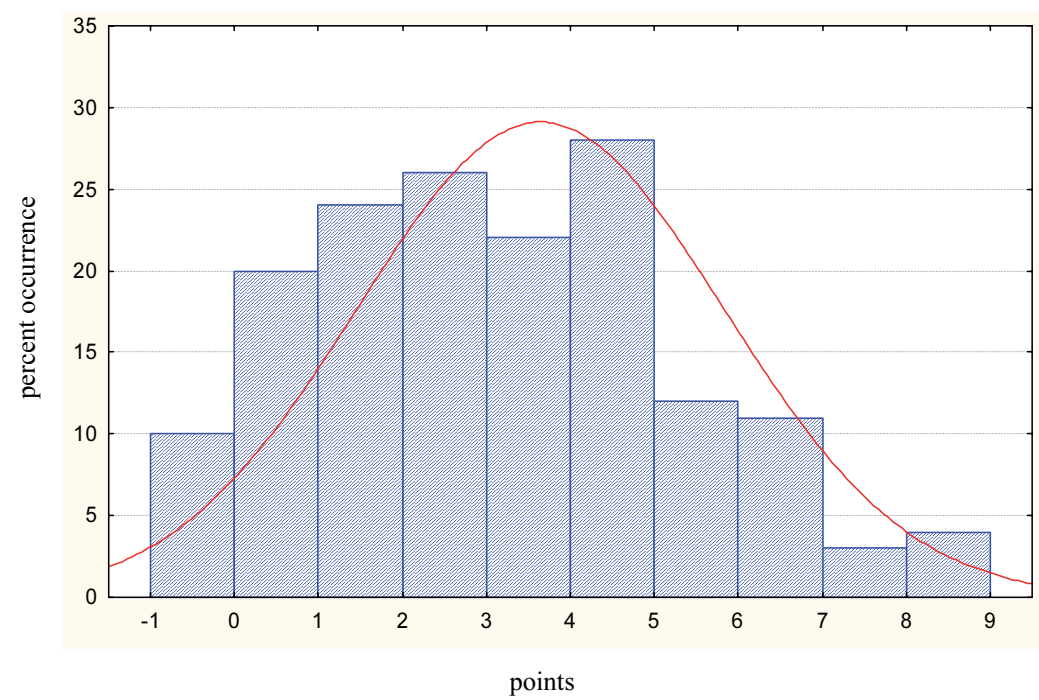

Table no. 6 Average, minimal and maximal value of points gained in didactic test of "normal" pupils

\begin{tabular}{|c|c|c|c|c|c|}
\hline variable & average & $\begin{array}{c}\text { standard } \\
\text { deviation }\end{array}$ & $\begin{array}{c}\text { minimal } \\
\text { value }\end{array}$ & $\begin{array}{c}\text { maximal } \\
\text { value }\end{array}$ & $\mathrm{N}$ \\
\hline test no. 2 & 3.64375 & 2.193033 & 0 & 9 & 160 \\
\hline
\end{tabular}

We can see the same dramatic difference of average point evaluation of both groups as in Kalkulie IV. The difference is 5 points (rounded off result).

\section{Research hypotheses}

H1 A mathematically gifted pupil chooses problems of higher cognitive demands than "normal" pupil. 
H2 A mathematically gifted pupil is more successful in solving tasks which need space imagination in comparison with a "normal" pupil.

H3 A mathematically gifted pupil is more successful in solving tasks based on logical thinking in comparison with a "normal" pupil.

H4 While solving divergent problems a mathematically gifted pupil finds more solutions in comparison with a "normal" pupil.

H5 A mathematically gifted pupil is able to correctly formulate his/her statements and arguments while defending them in comparison with a "normal" pupil.

H6 A mathematically gifted pupil is more successful in solving nonstandard tasks in comparison with a "normal" pupil.

Before testing the hypotheses $\mathrm{H} 1-\mathrm{H} 6$ we always formulated zero and alternative hypothesis and according to nominal character of the data they were tested by statistical method for nominal data analysis - chi-square test of independence for a pivot table.

If the variables had only two alternative qualities, the hypotheses were tested by statistic test chi-square test for a two-way contingency table.

\section{Conclusions}

1. Testing hypotheses and interpretation of the research results

The aim of the research focused on characteristics of mathematically gifted pupils was to involve and describe main signs and abilities of mathematically gifted pupils. To gain the data needed we used the standardized tests Kalkulie IV., nonstandardized didactic test in mathematics and nonstructured interview with mathematics teachers. To verify individual hypothesis we used methods of quantitative research. All hypotheses were tested on the significance level $\alpha=0.05$.

Statistical analysis of gained data confirmed that mathematically gifted pupils are more successful in solving logical tasks, tasks demanding space imagination and nonstandard tasks in comparison with "normal" pupils. In our test it was a task that $8^{\text {th }}$ graders could not had met before - combinatorial task. Moreover we showed that mathematically gifted pupils can find more correct solutions in solving divergent tasks in comparison with "normal" pupils. Hypothesis $\mathrm{H} 5$ indicated connection between belonging to a group and the ability to correctly formulate his/her statements and arguments while their advocacy. The value of coefficient $r_{\phi}=0.31$ showed low dependence between the phenomenon. 
Statistic analysis of the data did not confirm the hypothesis that mathematically gifted pupils prefer tasks of higher cognitive demandingness in comparison with "normal" pupils.

\section{Relations among individual gained data}

The results of the didactic test showed that better results gained on this test are connected with higher value of MQ gained in test Kalkulie IV. Therefore, we can presume that belonging to a group would be statistically important. It was confirmed by the point-biserial correlation coefficient.

We were also interested in how tight is the relation between belonging to a group (gifted pupils or "normal" pupils) and the result gained in didactic test. We tested the relation on the basis of point-biserial correlation coefficient. Proven tightness is considerable $\mathrm{r}_{\mathrm{bb}}=0.66$, which shows that belonging to a group predicts successfulness on test.

Overall we can say that the choice of tasks in didactic tests is good. It could be a diagnostic instrument for identification of giftedness.

\section{References}

1. CHRÁSKA, M. Metody pedagogického výzkumu. Praha: Grada, 2007. ISBN 978-80-247-1369-4.

2. NOVÁK, J. Kalkulie IV. Př́ručka. Brno: Psychodiagnostika, s. r. o., 2002.

3. NOVÁK, J. Vyšetření matematických schopností u dětí. Brno: Psychodiagnostika, s. r. o., 1997.

Mgr. Eva Hotová, Ph.D.,

Department of Mathematics,

Faculty of Education, Palacký University in Olomouc,

Žižkovo nám. 5, 77140 Olomouc,

eva.hotova@upol.cz 